\title{
SEISMIC MITIGATION EFFICIENCY STUDY OF THE COUPLING BEAM DAMPER IN THE SHEAR WALL STRUCTURE
}

\author{
Xin Huang \\ College of Airport, Civil Aviation University of China, Tianjin, China; \\ huangxin1395602@163.com
}

\begin{abstract}
Coupling beam damper can be easily repaired in the post-earthquake, which can dissipate the seismic energy of the structure in the earthquake action. In this paper, the seismic mitigation efficiency of the coupling beam damper in the shear wall structure is analysed by using the fast nonlinear analysis method. Meanwhile, the effect of the layout location and number of the coupling beam dampers on the seismic mitigation efficiency of the structure are studied. Finally, the effect of the performance parameter of the coupling beam damper on the seismic mitigation efficiency is also analysed. The results indicate that: the story shear force and the drift angle of the shear wall structure can be effectively decreased because of the coupling beam damper, and the maximum decreased amplification of the story drift angle and base shear force can reach up to $16.7 \%$ and $8.8 \%$ respectively. Relating to the decreased amplification of the base shear force, the decreased amplification of the story drift angle of the structure with coupling beam damper is obvious. The coupling beam damper installed in the upper part of the structure is more economical, because the deformation of the structural coupling beam is mainly concentrated in the upper part of the structure. To ensure economic of the structure with damper, the reasonable coupling damper performance parameter should be determinate according to the dynamic response of the shear wall structure in the earthquake action. The above research work can provide guidance for the seismic design of the shear wall structure.
\end{abstract}

\section{KEY WORDS}

Shear wall structure, Coupling beam damper, Earthquake action, Seismic mitigation efficiency, Damper optimal layout, Performance parameter of the damper

\section{INTRODUCTION}

To ensure the safety of buildings in the earthquake region, dampers are installed to dissipate the energy of the earthquake action in the building structure. The principle and design method of the structure with damper are studied by many scholars. According to the difference of the structural systems, the different dampers are used in the structure including soft steel dampers, viscoelastic dampers and friction pendulum dampers [1-4]. To improve the energy-dissipating capacity and deflection of the damper, the optimal design and test study of the damper were carried out [1], and the novel damper was also developed [2]. Meanwhile, the effect of the viscoelastic damper on the structural dynamic response was studied [3], and the shaking table test of the structure with damper was developed to analyse the seismic mitigation efficiency of the damper [4]. For the high-rise structure with the outrigger, the viscoelastic damper was installed in the outrigger floor, and the earthquake response of structure had been effectively decreased because of the damper action [5-6]. The calculation method of additional damping ratio of structure with damper based on linear equivalent method was studied, and the result showed that linear 
equivalent method can be adopt in structure energy dissipation design [7]. Meanwhile, the damper was also installed in the non-structural components to improve the seismic performance of the structure, the steel bar and U-shaped damper connection methods were adopted for the RC frame with the precast concrete cladding panels [8]. To improve the seismic mitigation efficiency of the structure, the effect of the location and number of the viscous dampers were also studied [9], and the economy of the structure with damper were analysed [10].

The shear wall is the basic lateral-resistance structural component of the high-rise structure. To ensure the anti-seismic safety of the shear wall, dampers can be set on the coupling beam to reduce the vibration, and the coupling beam damper is easy to replace in the postearthquake. At present, to improve the energy dissipation capacity of the damper in the coupling beam, the optimize design of the viscoelastic damper and the friction pendulum damper of the coupling beam were developed [11-12], and the influence of the coupling beam damping on the structural displacement and acceleration were analysed [13]. The current analysis put emphasis on the component design of the coupling beam damper, and the effect of the coupling beam damper on the high-rise structure with the frame- tube core system is mainly analysed. However, systematic studies on the seismic mitigation efficiency of the coupling beam damper on the shear wall structure rarely have been reported now. Moreover, the optimization of the location and quantity of the coupling beam damper are often ignored, but those analyses are very important to control the cost and the seismic mitigation efficiency of the high-rise structure. To provide seismic design guidance for coupling beam damper in shear wall structure, the seismic mitigation and layout method of coupling beam damper in shear wall structure should be systematic studied.

In this paper, the seismic mitigation efficiency of the shear wall structure with the coupling beam damper is systematic studied by using the fast nonlinear analysis method. Meanwhile, the effect of the layout location and number of the coupling beam dampers on the seismic mitigation efficiency of the structure are also analysed. Finally, the effect of the performance parameter of the coupling beam damper on the seismic mitigation efficiency of the structure is studied.

\section{ANALYSIS METHOD AND MODEL OF COUPLING BEAM DAMPER}

\section{Seismic mitigation analysis method}

The coupling beam damper can dissipate the structural energy by the plastic deform in the earthquake action. To analysis seismic mitigation efficiency of the shear wall structure with the coupling beam damper, the nonlinear property of the coupling beam damper can be simulated as the external nonlinear force by using the fast nonlinear analysis method [14]. Structural equilibrium equation can be expressed as:

$$
M \ddot{u}(t)+C \dot{u}(t)+K u(t)+R_{N L}(t)=R(t)
$$

Where $M$ is the mass matrix, $C$ is the damper matrix, $K$ is the stiffness matrix without damper stiffness; $\ddot{u}(t), \dot{u}(t), u(t)$ are the node acceleration, velocity and displacement, respectively; $R(t)$ and $R_{N L}(t)$ are the external load and nonlinear force of the damper, respectively.

To consider the linear load action of the nonlinear element, the elastic force is applied to Equation 1. Therefore, equilibrium equation 1 can be expressed as:

$$
M \ddot{u}(t)+C \dot{u}(t)+K^{\prime} u(t)=\bar{R}(t)
$$

Where $\bar{R}(t)=R(t)-R_{N L}(t)+K_{\mathrm{e}} u(t)$ is the external load, $K^{\prime}=K+K_{\mathrm{e}}, K_{e}$ is the stiffness matrix of the damper.

Equation 2 can be transferred to the motion equation in the mode state coordinate system by using the Ritz vector, and the internal force of the nonlinear element can be solved by the iterative calculation. 


\section{Model of the coupling beam damper}

The coupling beam damper is a mild steel damper, which dissipates the earthquake energy by the shear force deformation of the coupling beam in the earthquake action. The relationship of the force and displacement of the coupling beam damper is listed in Equation 3.

$$
f=\alpha k d_{k}+(1-\alpha) f_{\beta}
$$

Where $d_{k}$ is the deflection of the damper, $k$ is the stiffness of the damper, $\alpha$ is the yielding stiffness ratio, $f_{\beta}$ is the yielding strengthen, $z$ is the internal parameter of the resilience model.

\section{SEISMIC MITIGATION EFFICIENCY OF THE COUPLING BEAM DAMPER}

To analyse the seismic mitigation efficiency of the coupling beam damper in the shear wall structure, the dynamic responses of the shear wall structure with and without the coupling beam damper are analysed.

\section{Analysis model of the shear wall structure}

The height of the building is $34.1 \mathrm{~m}$, and the typical floor height is $4.5 \mathrm{~m}$. Shear wall structural system is adopted for the building [15], and the thickness of shear wall is $200 \mathrm{~mm}$. The heights of the coupling beam are $2550 \mathrm{~mm}$ and $2650 \mathrm{~mm}$. The strength grade of C40 is adopted for the concrete, and the HRB grade reinforcement is adopted. Dynamic responses of the shear wall structure are analysed by using ETABS v9.7 software based on the fast nonlinear analysis method [14].

Initial stiffness of the coupling beam damper is $100 \mathrm{kN} / \mathrm{mm}$, the yield load is $150 \mathrm{kN}$, the yield displacement is $1.5 \mathrm{~mm}$, and the post-yield stiffness ratio is 0.05 . The layout of the shear wall and the coupling beam damper are descripted in Figure 1. The four dampers are installed in the Xdirection and the three dampers are installed in the Y-direction in every story of the shear wall structure.

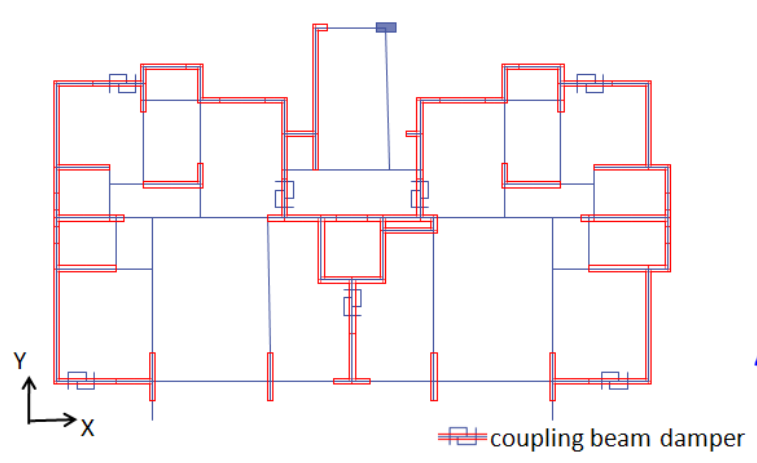

(a)

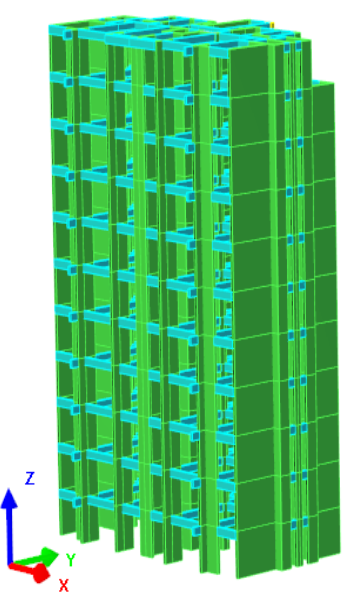

(b)

Fig. 1-The layout of the shear wall and the coupling beam damper: (a) damper layout, (b) 3-D model

Dynamic history analysis of shear wall structure is developed by using the El-Centro wave $(1940, \mathrm{EW})$ and the Loma-Prieta wave $(1989, \mathrm{EW})$. The duration of the earthquake wave is $20 \mathrm{~s}$, and the maximum amplitude of the acceleration is $0.55 \mathrm{~m} / \mathrm{s}^{2}$. The time history curve and acceleration spectra of the earthquake waves are shown in Figure 2. 


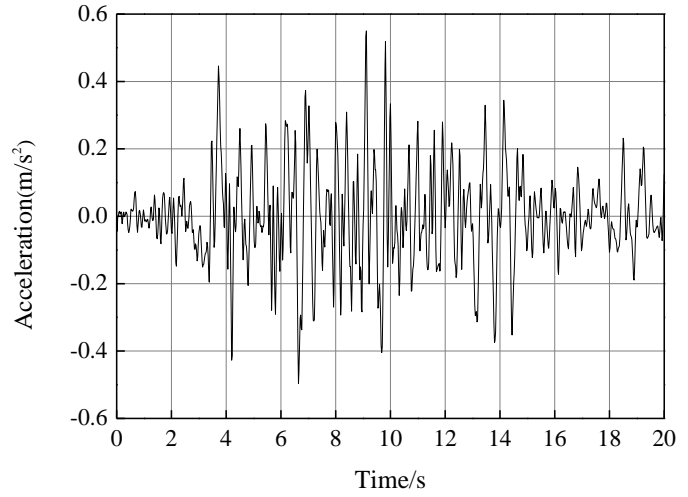

(a)

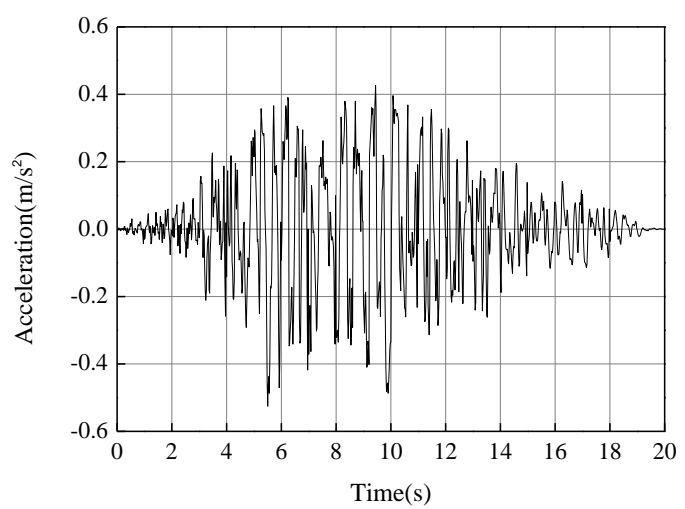

(b)

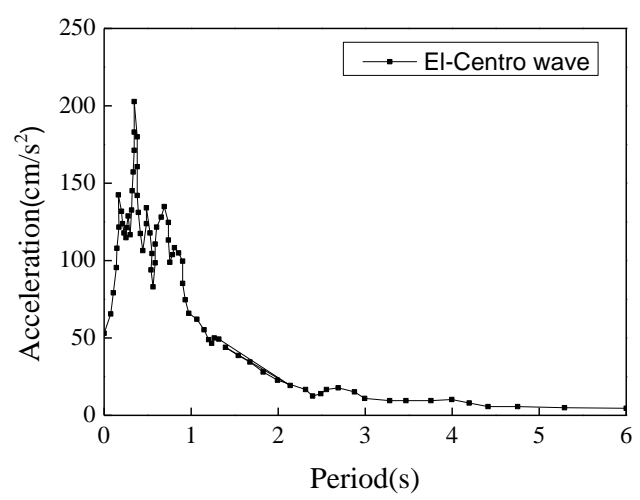

(b)

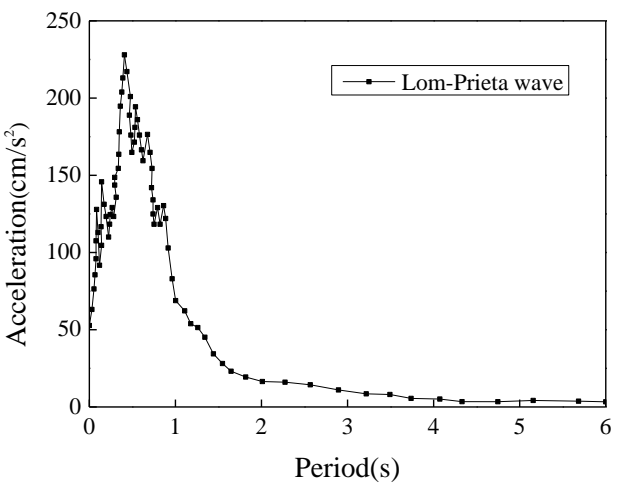

(c)

Fig. 2- The time history curve and acceleration spectra of the earthquake waves : (a) the El-Centro history curve, (b) the El-Centro Spectra, (c) the Lom-Prieta history curve, (d) the Lom-Prieta Spectra

\section{Seismic mitigation efficiency}

To analysis seismic mitigation efficiency of the coupling beam damper, story drift angel and base shear force of shear wall structure with and without damper are compared. Considering the space of the building, the coupling beam dampers are installed from the 3th story to the 10th story of the structure.

The shear force and drift angel of the structural story in frequent earthquake action are listed in Table1, Figure 3 to Figure 6. 
Article no. 2

THE CIVIL ENGINEERING JOURNAL 1-2021

ENGINEERING

JOURNAL

Tab. 1 - Drift angle and base shear force of the structure with and without damper

\begin{tabular}{|c|c|c|c|c|c|c|}
\hline \multicolumn{2}{|c|}{$\begin{array}{c}\text { Condition } \\
\text { Earthquake }\end{array}$} & \multicolumn{2}{|c|}{ Structure without damper } & \multicolumn{3}{|c|}{ Structure with damper } \\
\cline { 3 - 7 } wave & Drift angel & $\begin{array}{c}\text { Base shear } \\
\text { force }(\mathrm{kN})\end{array}$ & Drift angel & \multicolumn{2}{|c|}{$\begin{array}{c}\text { Base shear } \\
\text { force }(\mathrm{kN})\end{array}$} & $\begin{array}{c}\text { Additional } \\
\text { damping ratio }\end{array}$ \\
\hline $\begin{array}{c}\text { El-Centro } \\
\text { wave }\end{array}$ & $\mathrm{X}$ & $1 / 1484$ & 3255 & $1 / 1663$ & 3343 & $1.7 \%$ \\
\cline { 2 - 7 } & $\mathrm{Y}$ & $1 / 2107$ & 3385 & $1 / 2274$ & 3280 & $1.0 \%$ \\
\hline $\begin{array}{c}\text { Loma-Prieta } \\
\text { wave }\end{array}$ & $\mathrm{X}$ & $1 / 1049$ & 4904 & $1 / 1259$ & 4472 & $2.0 \%$ \\
\cline { 2 - 7 } & $\mathrm{Y}$ & $1 / 1632$ & 4638 & $1 / 1687$ & 4449 & $0.5 \%$ \\
\hline
\end{tabular}

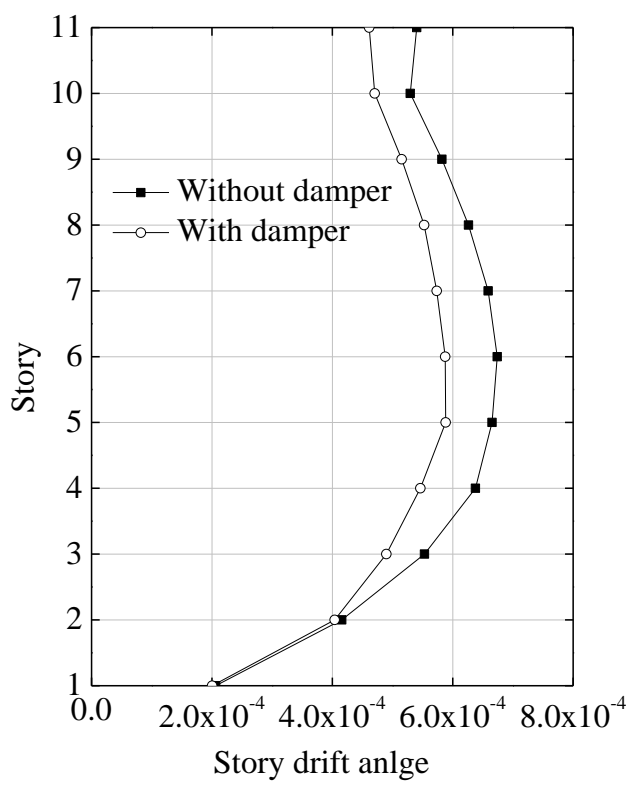

(a)

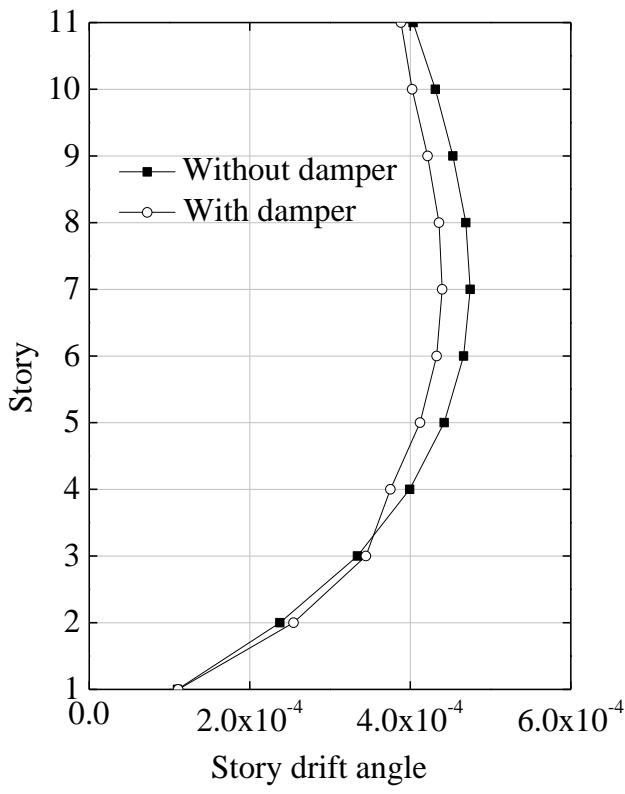

(b)

Fig. 3 - Story drift angle of the structure with and without damper in the El-Centro earthquake action: (a) X-direction; (b) Y-direction 


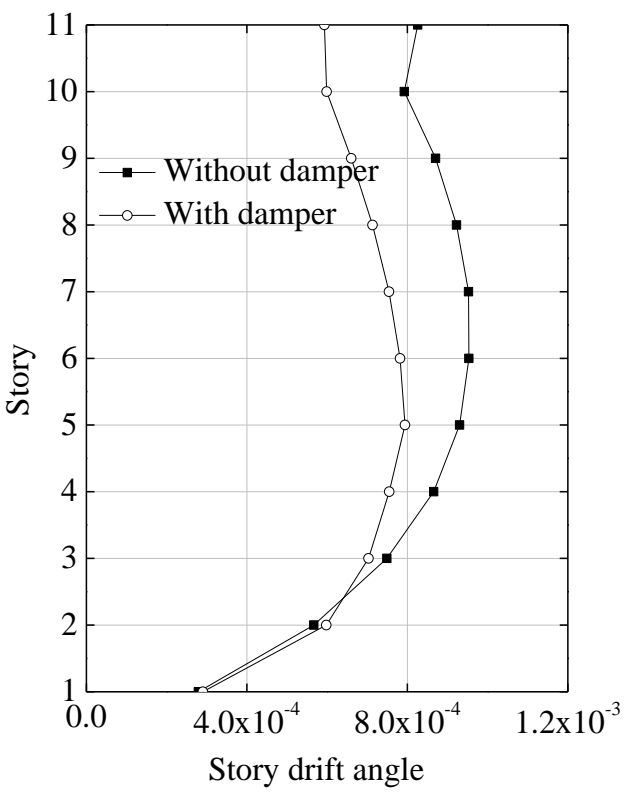

(a)

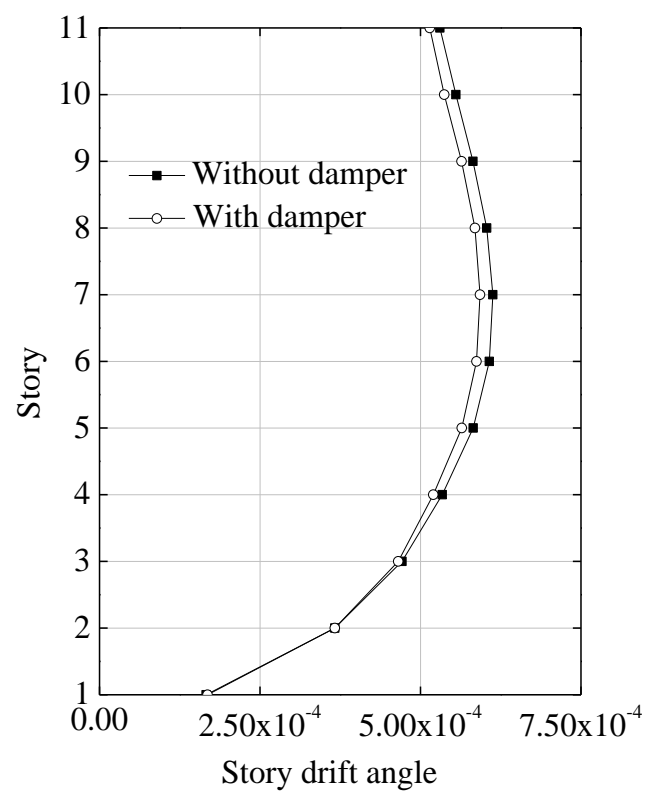

(b)

Fig. 4 - Story drift angle of the structure with and without damper in the Loma-Prieta earthquake action: (a)X-direction story, (b) Y-direction

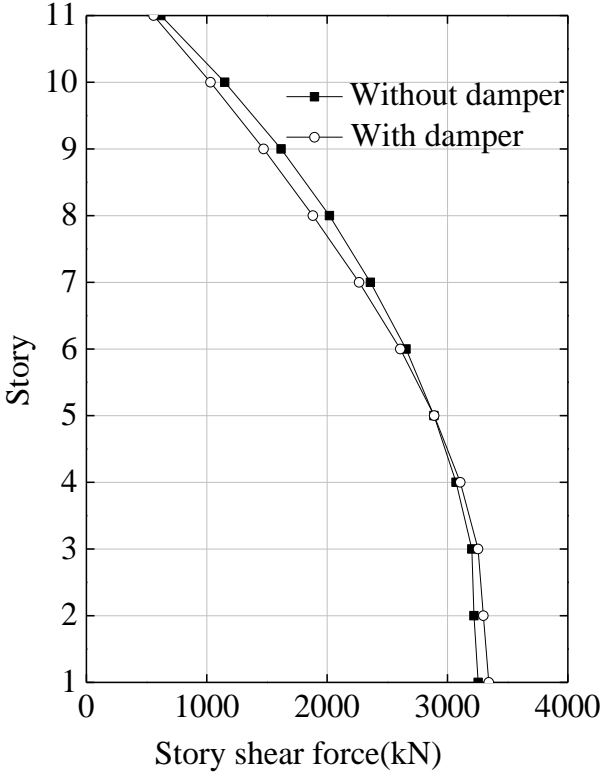

(a)

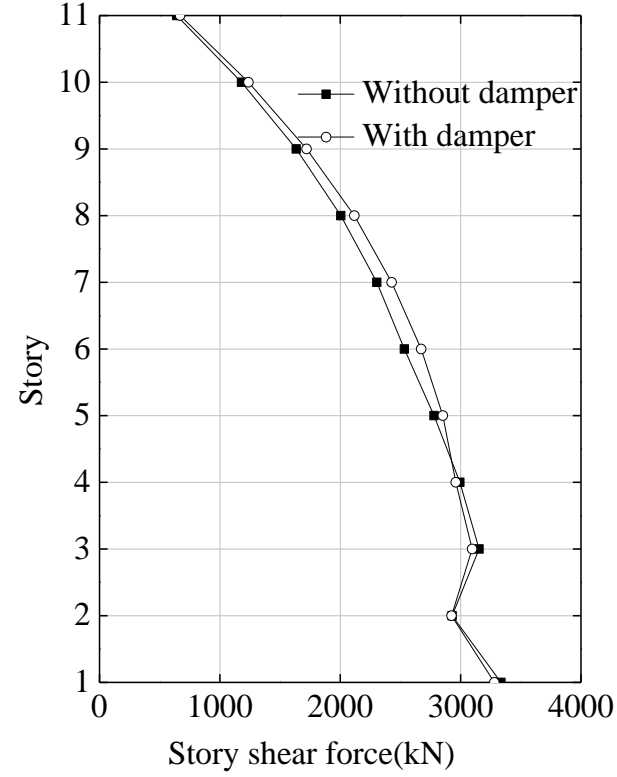

(b)

Fig. 5 - Story shear force of the structure with and without damper in the El-Centro earthquake action: (a)X-direction, (b) Y-direction 


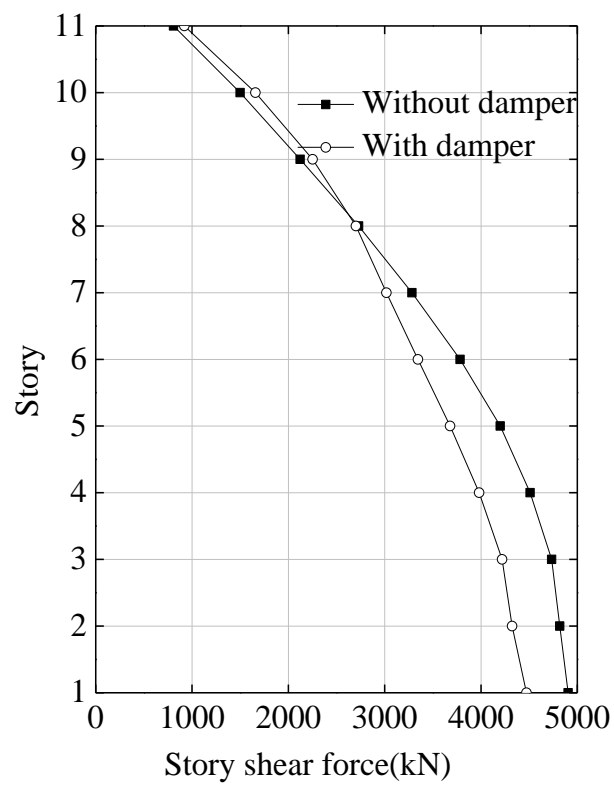

(a)

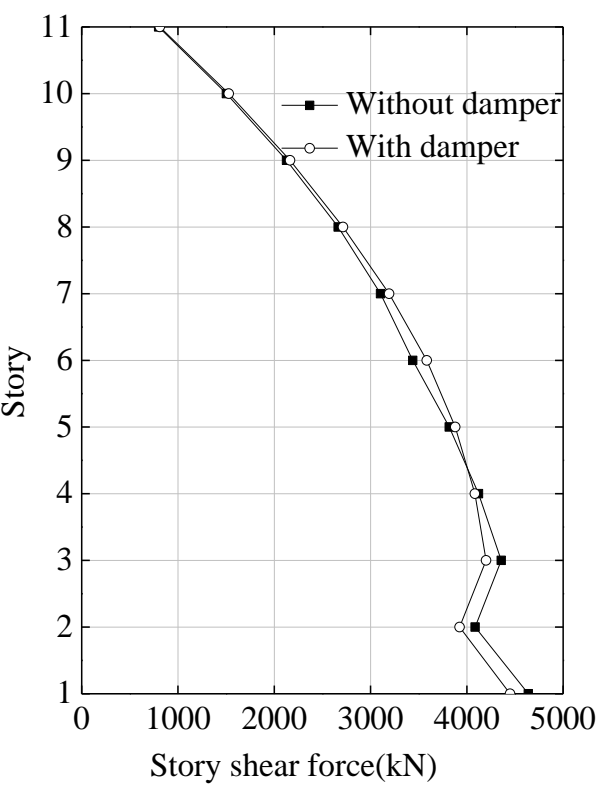

(b)

Fig. 6 - Story shear force of the structure with and without damper in the Loma-Prieta earthquake action: (a)X-direction, (b) Y-direction

From the Table 1 and Figure 3 to Figure 6, relating to the structure without damper, the story drift angle can be decreased from 1/2017 to $1 / 2274$ and the base shear force can be decreased from $3385 \mathrm{kN}$ to $3280 \mathrm{~N}$ of the structure with damper in the Y-direction in the El-Centro earthquake action. The similar conclusions can be obtained for the Loma-Prieta wave action, for example, the story drift angle can be decreased from 1/1632 to 1/1687 and the base shear force can be decreased from $4638 \mathrm{kN}$ to $4449 \mathrm{~N}$ of the structure with damper in the Y-direction. The additional damping ratio of the structure with coupling beam damper can reach up to $1.7 \%$ and $2.0 \%$ in the El-Centro earthquake action in the $\mathrm{X}$-direction and $\mathrm{Y}$-direction respectively.

The results indicate that story shear force and drift angle of structure can be effectively decreased because of the energy dissipation action of the coupling beam damper, which can ensure safety of the major structure.

To measure the seismic mitigation efficiency of coupling beam damper on the shear wall structure, the dimensionless parameters are used to represent the reduced amplification of structural dynamic responses. The reduced amplification of structural story drifty angle and base shear force are calculated respectively by using Equation 4 and Equation 5 . The seismic mitigation efficiency of coupling beam damper is shown in Figure 7.

$$
\begin{gathered}
D_{d}=\left(D_{1}-D_{2}\right) / D_{1} \\
D_{V}=\left(V_{1}-V_{2}\right) / V_{1}
\end{gathered}
$$

Where, $D_{d}$ and $D_{V}$ are the maximum reduced amplification of the structural story drift angle and base shear force respectively, $D_{1}$ is the structural story drift angle without considering damper action, $D_{2}$ is the structural story drift angle considering damper action, $V_{1}$ is the structural base shear force without considering damper action, $V_{2}$ is the structural base shear force considering damper action. 


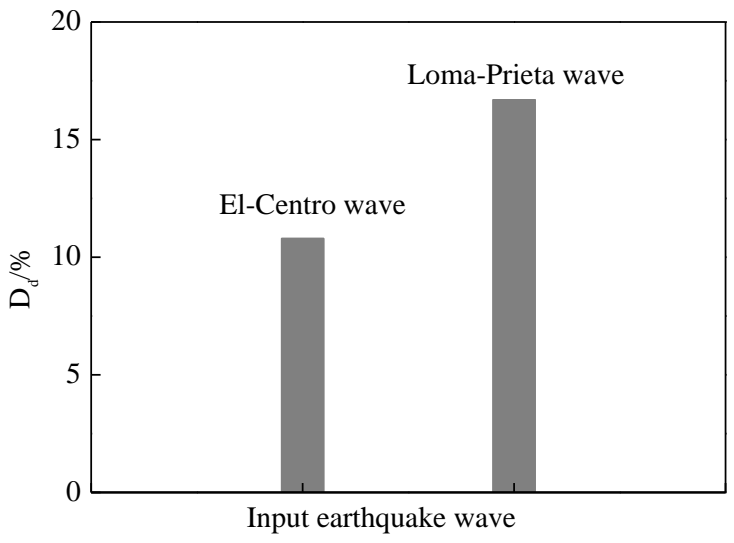

(a)

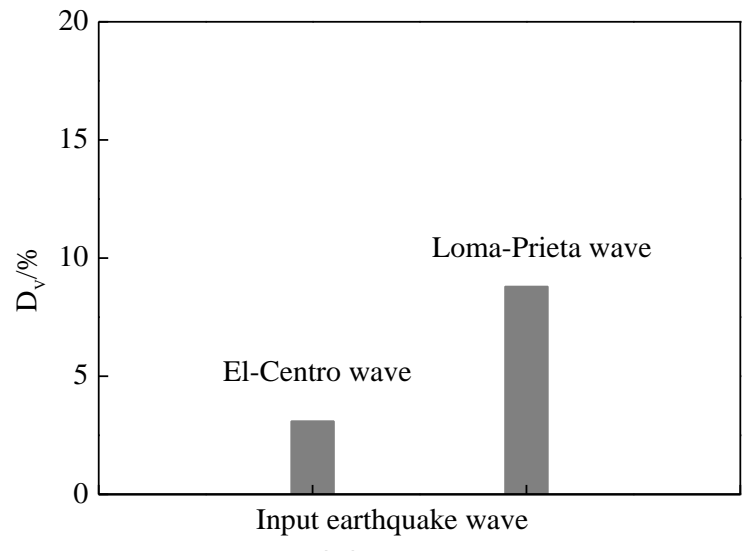

(b)

Fig. 7- Seismic mitigation efficiency of shear wall structure by using the coupling beam damper:

(a) reduced amplification of story drift angle, (b) reduced amplification of story shear force

From the Figure 7 , the decreased amplification of the story drift angle is obvious relating to that of the base shear force, for example, the decreased amplitude of the story drift angle is $16.7 \%$, and the decrease amplitude of the base shear force is $8.8 \%$ in the Loma-Prieta earthquake wave action. Coupling beam damper can be adopted to improve the seismic performance of shear wall structure when the story drift angle of structure can't satisfy seismic design code requirement.

\section{THE EFFECT FACTOR ANALYSIS OF COUPLIN BEAM DAMPER}

\section{Optimal layout location and number of coupling beam damper}

To analyse the influence of the layout location and number of the dampers, two kinds of the layout schemes of the coupling beam dampers of the structure are considered. The coupling beam dampers are installed from the 3th story to the 10th story for the Scheme A, and the coupling beam dampers are only installed in the 7 th to the 10th story for the Scheme B. Relating to the Scheme A, the number of dampers in the Scheme $B$ are reduced by half.

The story shear force and drift angel of the Scheme $A$ and $B$ in the frequent earthquake action are listed in Table 2 and Figure 8 to Figure 11.

Tab. 2 - Drift angle and base shear force of the Scheme A and Scheme B

\begin{tabular}{|c|c|c|c|c|c|c|c|}
\hline \multicolumn{2}{|c|}{$\begin{array}{c}\text { Condition } \\
\text { Earthquake } \\
\text { wave }\end{array}$} & \multicolumn{4}{|c|}{ Scheme A } & \multicolumn{3}{c|}{ Scheme B } \\
\cline { 2 - 7 } & Drift angel & $\begin{array}{c}\text { Base shear } \\
\text { force }(\mathrm{kN})\end{array}$ & $\begin{array}{c}\text { Additional } \\
\text { damping } \\
\text { ratio }\end{array}$ & Drift angel & $\begin{array}{c}\text { Base shear } \\
\text { force }(\mathrm{kN})\end{array}$ & $\begin{array}{c}\text { Additional } \\
\text { damping } \\
\text { ratio }\end{array}$ \\
\hline \multirow{2}{*}{$\begin{array}{c}\text { El-Centro } \\
\text { wave }\end{array}$} & $\mathrm{X}$ & $1 / 1663$ & 3064 & $1.7 \%$ & $1 / 1643$ & 3081 & $1.5 \%$ \\
\cline { 2 - 8 } & $\mathrm{Y}$ & $1 / 2274$ & 3449 & $1.0 \%$ & $1 / 2216$ & 3422 & $0.6 \%$ \\
\hline $\begin{array}{c}\text { Loma- } \\
\text { Prieta } \\
\text { wave }\end{array}$ & $\mathrm{X}$ & $1 / 1259$ & 4472 & $2.0 \%$ & $1 / 1206$ & 4595 & $1.6 \%$ \\
\cline { 2 - 8 } & $\mathrm{Y}$ & $1 / 1687$ & 4449 & $0.5 \%$ & $1 / 1645$ & 4545 & $0.3 \%$ \\
\hline
\end{tabular}




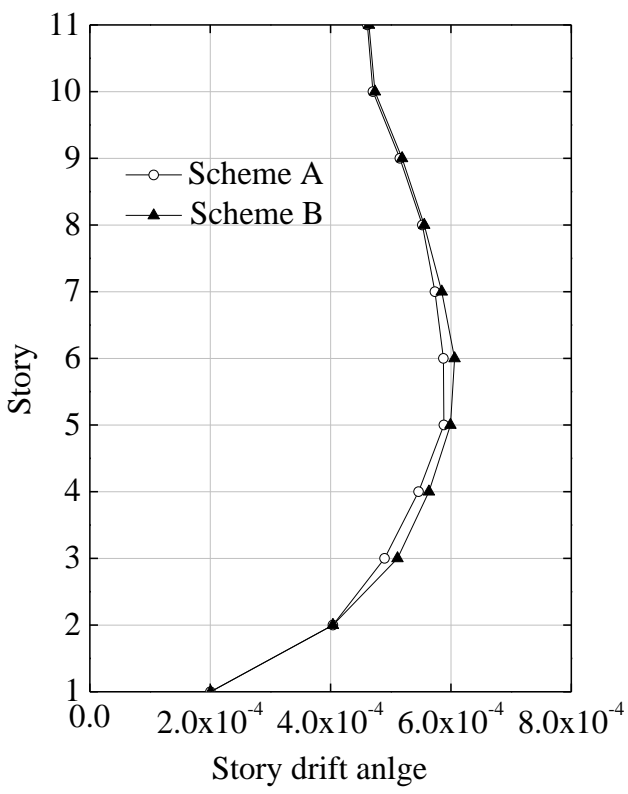

(a)

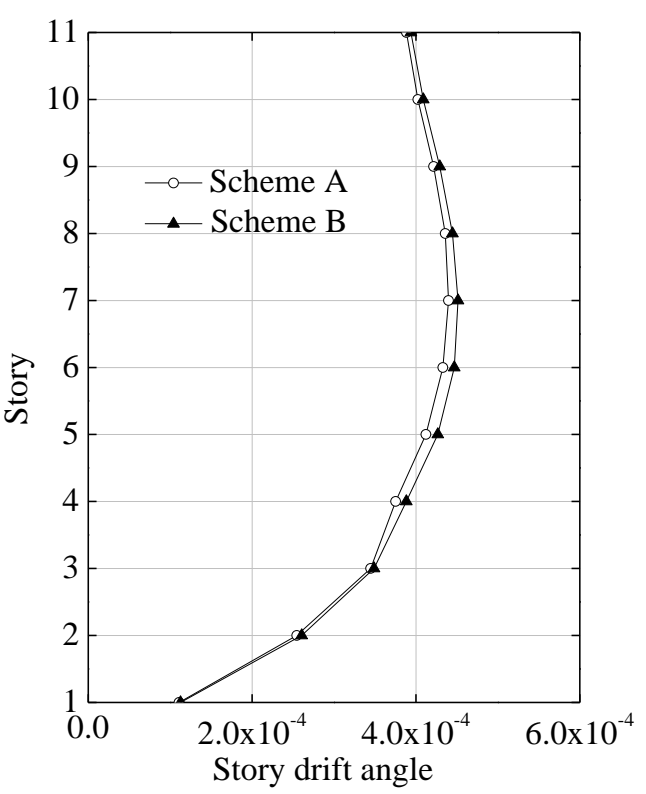

(b)

Fig. 8 - Story drift angle of the Scheme $A$ and Scheme B in the El-Centro earthquake action: (a) $X$ direction; (b) Y-direction

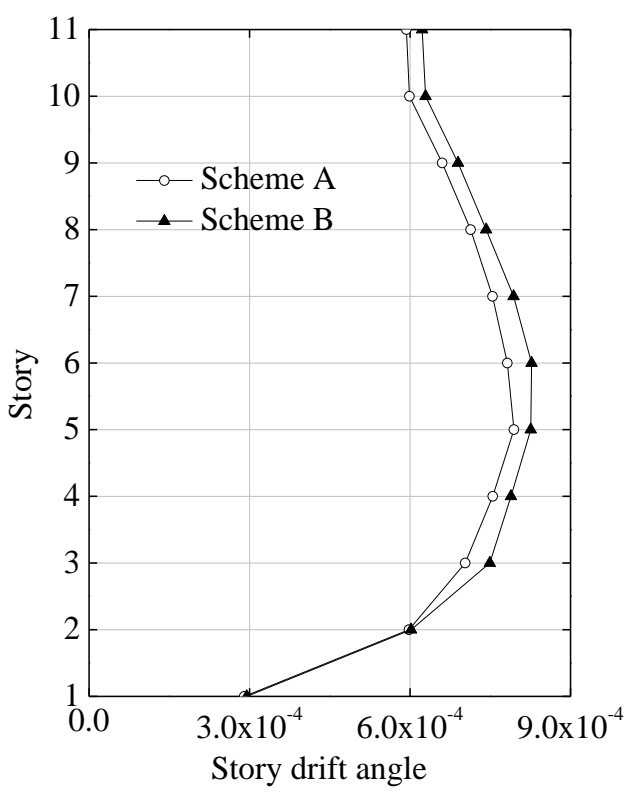

(a)

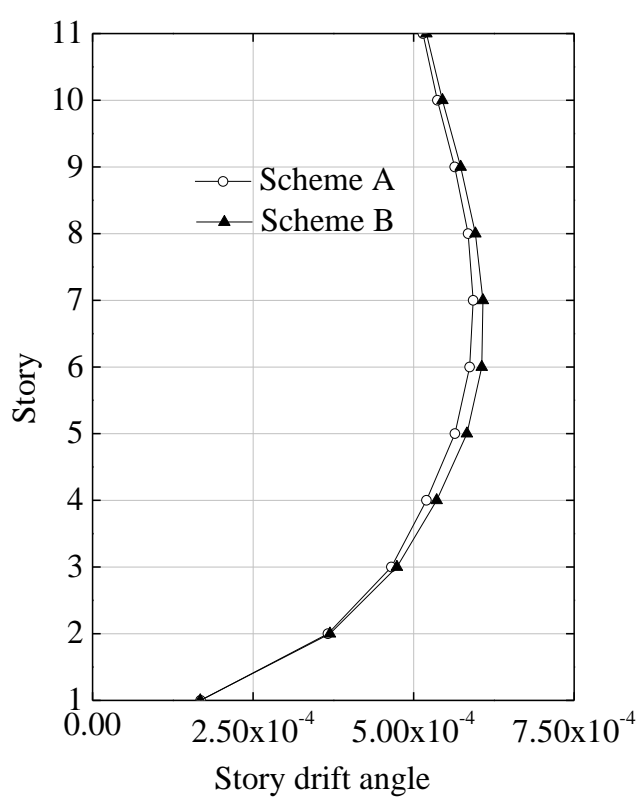

(b)

Fig. 9 - Story drift angle of the Scheme $A$ and Scheme $B$ in the Loma-Prieta earthquake action: (a) $X$-direction; (b) Y-direction 


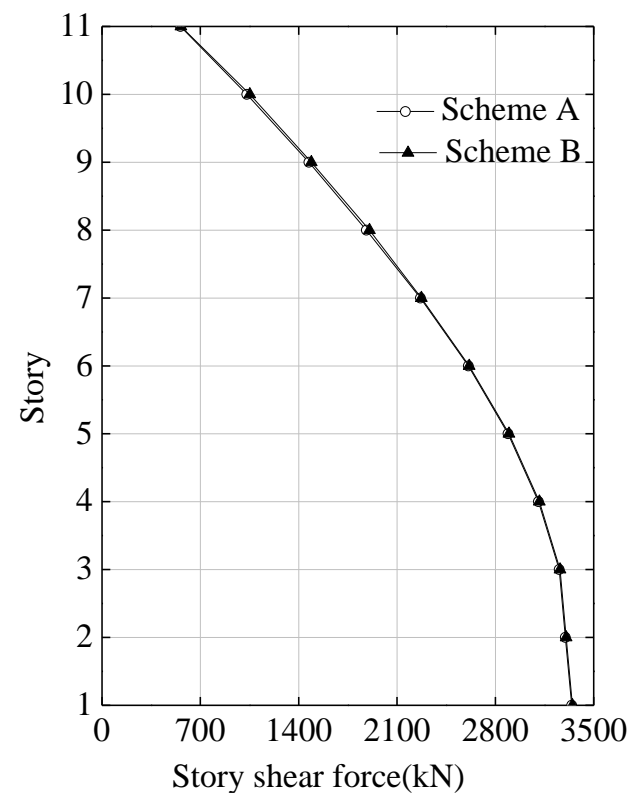

(a)

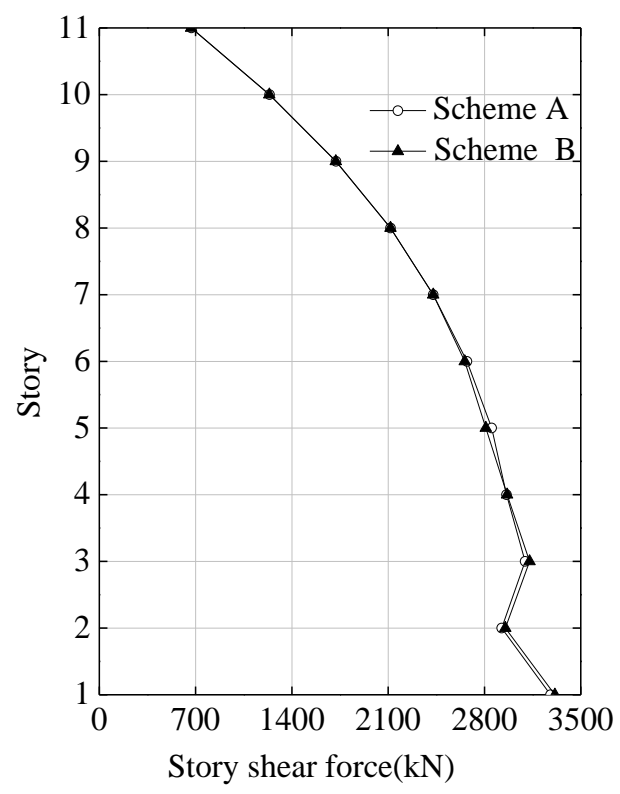

(b)

Fig. 10 - Story shear force of the Scheme A and Scheme B in the El-Centro earthquake action: (a) X-direction, (b) $Y$-direction

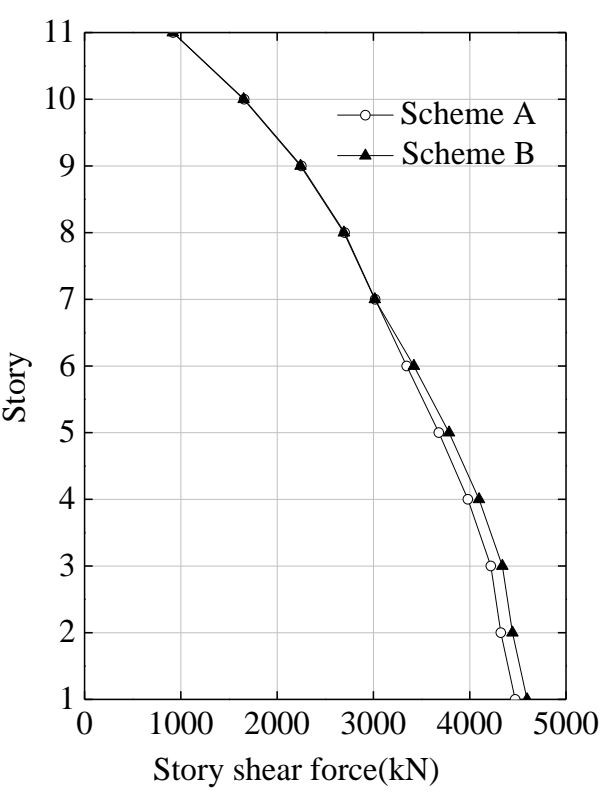

(a)

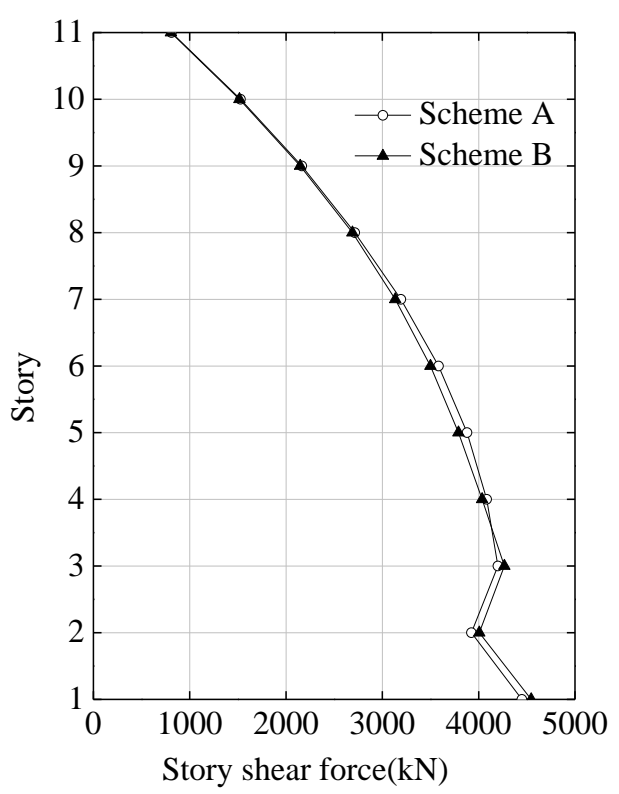

(b)

Fig. 11 - Story shear force of the Scheme $A$ and Scheme $B$ in the Loma-Prieta earthquake action: (a)X-direction, (b) $Y$-direction

From the Table 2 and Figure 8 to Figure 11, the story drift angle of the Scheme $A$ and Scheme B are $1 / 1663$ and $1 / 1643$ respectively, and the story shear force of the Scheme $A$ and Scheme $B$ are $3449 \mathrm{kN}$ and $3422 \mathrm{kN}$ in the X-direction in the El-Centro earthquake action. Meanwhile, the additional damper ratio of the Scheme A and Scheme B is $1.7 \%$ and $1.5 \%$ respectively. The similar conclusions can be obtained for the Loma-Prieta wave action.

It shows that the seismic mitigation efficiency of the Scheme B is not obviously lower than that of the Scheme A. The reason is that the deformation of the structural coupling beam is mainly 
concentrated in the upper part of the structure because the deformation of the shear wall structure belongs to the bending deformation, so it is more economical when the coupling beam dampers are installed in the upper part of the structure.

\section{Performance parameter of coupling beam damper}

To analyse the effect of the performance parameter of the coupling beam damper, dynamic responses of the shear wall with different performance parameter are analysed, and the Parameter one and the Parameter two of the coupling beam damper are listed in Table 3 . The energy dissipation capacity of Parameter two is large than that of the Parameter one. The story shear force and drift angel of the structure are listed in Table 4.

Tab. 3 - The performance parameter of the coupling beam damper

\begin{tabular}{|c|c|c|c|c|}
\hline $\begin{array}{c}\text { Performance } \\
\text { parameter }\end{array}$ & $\begin{array}{c}\text { Initial stiffness } \\
(\mathrm{kN} / \mathrm{mm})\end{array}$ & Yield load $(\mathrm{kN})$ & $\begin{array}{c}\text { Yield } \\
\text { displacement/mm }\end{array}$ & $\begin{array}{c}\text { Post-yield stiffness } \\
\text { ratio }\end{array}$ \\
\hline Parameter one & 100 & 150 & 1.50 & 0.05 \\
\hline Parameter two & 150 & 250 & 1.67 & 0.05 \\
\hline
\end{tabular}

Tab. 4 - Drift angel and base shear force of the structure with the Parameter one and the Parameter two

\begin{tabular}{|c|c|c|c|c|c|}
\hline \multirow{3}{*}{\multicolumn{2}{|c|}{$\begin{array}{l}\text { Earthquake } \\
\text { wave }\end{array}$}} & \multirow{2}{*}{\multicolumn{2}{|c|}{ Parameter one }} & \multirow{2}{*}{\multicolumn{2}{|c|}{ Parameter two }} \\
\hline & & & & & \\
\hline & & \multirow{2}{*}{$\begin{array}{c}\text { Drift angel } \\
1 / 1663 \\
\end{array}$} & \multirow{2}{*}{$\begin{array}{c}\text { Base shear force } \\
\text { (kN) }\end{array}$} & \multirow{2}{*}{$\begin{array}{c}\text { Drift angel } \\
1 / 1667 \\
\end{array}$} & \multirow{2}{*}{$\begin{array}{c}\text { Base shear force } \\
\text { (kN) }\end{array}$} \\
\hline \multirow{2}{*}{ El-Centro wave } & $x$ & & & & \\
\hline & $Y$ & $1 / 2274$ & 3449 & $1 / 2291$ & 3430 \\
\hline \multirow{2}{*}{$\begin{array}{l}\text { Loma-Prieta } \\
\text { wave }\end{array}$} & $x$ & $1 / 1259$ & 4472 & $1 / 1269$ & 4444 \\
\hline & $Y$ & $1 / 1687$ & 4449 & $1 / 1689$ & 4417 \\
\hline
\end{tabular}

From Table 4, relating to the structure with the Parameter one, the story drift angle of the structure is $1 / 1667$ and base shear force is $2974 \mathrm{kN}$, y direction story drift angle is $1 / 2291$ and base shear force is $3455 \mathrm{kN}$ in the X-direction in El-Centro wave action of the structure with the parameter two. The biggest reduced amplification of story shear force is $3 \%$ in the El-Centro earthquake action because of the performance parameter change of the coupling beam damper. The results indicate that the drift angle and the base shear force of the shear wall structure has not obviously difference for the performance parameter one and two of the coupling damper, and the reason is that the damper with the high performance parameter cannot play obvious effect because of shear wall structure deflection limit in the earthquake action. To ensure economic of the structure with damper, the reasonable performance parameter of the coupling damper should be determinate according to the dynamic response of the shear wall structure in the earthquake action. 


\section{CONCLUSIONS}

The seismic mitigation efficiency of coupling beam damper in the shear wall structure was analysed, and the effect of the layout location, number and performance parameter of the coupling beam dampers were also studied in this paper. The following conclusions were obtained:

(1) The story shear force and drift angle of shear wall structure can be effectively decreased because of coupling beam damper action, for example, the story drift angle can be decreased from $1 / 2017$ to $1 / 2274$ and the base shear force can be decreased from $3385 \mathrm{kN}$ to $3280 \mathrm{~N}$ of the structure with damper in the Y-direction in the El-Centro earthquake action.

(2) The decreased amplification of the story drift angle is obvious relating to that of the base shear force, for example, the maximum decreased amplitude of the story drift angle is $16.7 \%$, and the decrease amplitude of the base shear is $8.8 \%$ in the Loma-Prieta earthquake wave action.

(3) The coupling beam damper installed in the upper part of the structure is more economical, because the deformation of the shear wall structure belongs to the bending deformation, for example, the additional damper ratio of the Scheme A and Scheme B is $1.7 \%$ and $1.5 \%$ respectively.

(4) The seismic mitigation efficiency has not obviously difference for the Parameter one and Parameter two of the coupling damper. To ensure economic of the structure with damper, the reasonable performance parameter of the coupling damper should be determinate according to the dynamic response of the shear wall structure in the earthquake action.

\section{ACKNOWLEDGEMENTS}

The authors gratefully acknowledge the support of this research by the national university basic science project (3122018C014) and the Research initiation fund of Civil Aviation University of China (Grant No. 2020KYQD40) sponsored.

\section{REFERENCES:}

[1] Jarrahi $H$, Asadi A, Khatibinia M, Etedali S. Optimal design of the rotational friction dampers for improving seismic performance of inelastic structures. Journal of Building Engineering, 2020, 27: 100960.

[2] Xu L H, Xie X S, Li Z X. Development and experimental study of a self-centering variable damping energy dissipation brace. Engineering Structures, 2018;160:270-280.

[3] Gong S M, Zhou Y, Ge P. Seismic analysis for tall and irregular temple buildings: A case study of strong nonlinear viscoelastic dampers. Structural design of tall and special building, 2017;26:e1352.

[4] Cai WH, Yu B J, Kaewunruen S. Shaking Table Tests of Suspended Structures Equipped with Viscous Dampers. Applied Sciences, 2019,9, 2616; doi:10.3390/app9132616.

[5] Kim H S, Kang J W. Smart outrigger damper system for response reduction of tall building subjected to wind and seismic excitations. International journal of steel structures, 2017;17(4):1263-1272.

[6] Lin P C, Takeuchi T, Matsui R. Seismic performance evaluation of single damped-outrigger system incorporating buckling-restrained braces. Earthquake engineering and structural dynamics, 2018;47:23432365.

[7] Wang Qi, Gan Gang. Calculation of effective additional damping ratio of energy dissipation structure based on linear equivalent method. Journal of Building Structures, 2012, 33(11): 46-52(in chinese).

[8] Jiang $Q$, Wang $H$ Q, Feng $Y L$ et.al. Seismic performance analysis of a damage-controlling RC frame with damping cladding panels. Engineering mechanics, 2019, 36(10): 144-151(in chinese).

[9] De Domenicoa D, Ricciardia G, Takewakib I. Design strategies of viscous dampers for seismic protection of building structures: A review. Soil dynamics and earthquake engineering, 2019, 118: 144-165.

[10] Shi S, Du D S, Wang S G et.al. Assessment of reinforcement scheme for a high-rise steel structure based on seismic resilience and reinforcement benefit ratio. China civil engineering journal, 2019, 52(11): 111 (in chinese). 
[11] Zhang Z, Ou J P, Li D S, Zhang S F. Optimization Design of Coupling Beam Metal Damper in Shear Wall Structures. Applied Sciences, 2017,7, 137; doi:10.3390/app7020137.

[12] Wang T, Yang F L, Wang X, Cui Y. Experimental Study on a Hybrid Coupling Beam With a Friction Damper Using Semi-steel Material. Frontiers in Materials, 2019, 6, doi:10.3389/frmats.2019.00135.

[13] Renee M L, Constantin C, Michael M. Viscoelastic coupling dampers for the enhanced multiple seismic hazard level performance of high-rise buildings. Earthquake Spectra, 2018, 34(4): 1847-1867.

[14] Chinese version of the ETABS.2004. Beijing Golden civil software technology company and China architecture standard design and Research, China Architecture and Building Press: Beijing, China (in Chinese).

[15] Code for seismic design of buildings (GB50011-2016). 2016. China Ministry of Construction, China Architecture and Building Press: Beijing, China (in Chinese). 